\title{
Literárna história jubiluje s Evou Fordinálovou
}

\section{Viera Žemberová (Prešov)}

Cesty k výskumu slovenskej stredovekej literatúry viedli Evu Fordinálovú (17. 12. 1941 v Borskom Mikuláši) viacerými smermi, aké jej spoločenské vedy ponúkali a ona ich vždy tvorivo a híbavo zapojila do svojho celoživotného programu: poznat’ z národnej minulosti všetko, čo nás utvára v čase a na kontinente ako vzdelané a kultúrne etnikum, teda dôkladne sa orientovat i v tom, čím sa stávame pre svoje okolie natrvalo jedineční a zaujímaví. Takýto zámer Eva Fordinálová vniesla aj do svojho života nasycovaného humanitou, empatiou a pokorou voči tomu, čo utváralo jej život aj mimo pracovísk Slovenskej akadémie vied, ale i to, čím sa zbližovala s lokalitou Skalice, kde ukotvila svoje súkromie.

Komornost' aj subtilita jej prejavu sa naplnili v zahĺbenej reflexii zbierky poézie Vôña Záhoria (1997). Rešpekt voči životu, jeho poslaniu a hodnotám rozvíjala v príhovoroch Ranné zamyslenia (2001). Literárny zemepis si v nej našiel autorku Literárnej mozaiky Senice (1998). Štúdium osobností prekračujúcich svoj tieň uzatvorila prácou Karol Korelič a americkoslovenské robotnicke hnutie (1988). Kultúrnej publicistike sa venovala a venuje dlhé roky svojej prítomnosti v literárnej histórii a nie jeden výstup zverejnila pod pseudonymom Eva Záborská. Pracovňu v dnešnom Ústave slovenskej literatúry SAV zamenila pred rokmi za prednáškovú miestnosṫ a pozorných študentov slovakistiky na Trnavskej univerzite.

Natrvalo sa epicentrom literárnohistorického výskumu Evy Fordinálovej stala slovenská stredoveká literatúra, ktorú doplnila svojou prácou Stretnutie so starším pánom alebo Tragoedia Augustina Doležala (1993), ale predovšetkým troma návratmi k osobnosti a tvorbe, ale i ozvennosti v slovenskej kultúre, literatúre a spoločnosti, ktoré sa napojili na materiálový, textový, kontextový a sémantický prieskum poézie Jána Hollého: Aký si, JánHollý? (1985), Ján Hollý (1785-1849) [2003] a nateraz posledným jej slovom venovaným výnimočnej osobnosti slovenského duchovného a literárneho života, Ján Hollý v slovenskom národno-kultúrnom vedomi (2007).

Výskum venovaný stredovekej literatúre, popri horizonte jej časovej otvorenosti, žiada si od literárneho historika aj čosi navyše okrem serióznej odbornej zorientovanosti v predmete výskumu a v podloží sledovaného javu, je ňou kultúrne ladená intuícia, odvaha vydávat sa za novými prameňmi a trpezlivost́ pri dopíňaní dostupného dokumentárneho materiálu, azda ešte viac pri korigovaní zafixovaného prijímania reálií či výkladov autorského literárneho a vývinového podložia.

Tieto požiadavky sprevádzajú v súznení zverejnený výskum profesorky Fordinálovej venovaný Jánovi Hollému. Naplno sa zrkadlí v jej návratoch k Hollému, ktorý - ako to dokladá svojím výskumom - zotrváva dodnes v priesečníku generácií, konceptov národnej literatúry, hodnoty lyrického slova a osobnostnej obety, teda tie, ktoré presahujú čas 
bytia jednotlivca, ako dopĺn̆a jubilantka: „,...] predsa sa ani o jednom básnikovi nevyslovilo tolko protirečivých turdeni [...] vieme, aký prinos znamená Hollého poézia v kontexte našej literatúry“. S premisou Hollého postavenia v dejinách slovenskej kultúry sa spájajú aj d’alšie nazeracie postoje literárnej historičky na dobu a básnika, lebo „, „... [ spol'ahnút'sa možno iba na hodnoty duševné - a medzi nimi najuyššie stoji láska $k$ slobode [...], nemôže byt’ slobodný ten, kto nie je mravne zrely“". Tézy literárnej historičky sa tak natrvalo zovreli istotami jej života, aby sa pri všetkom, čomu sa venovala, konfrontovala jazykom a metódami ústiacimi do ludskej múdrosti a jej uplatnenia sa tam, kde pôsobila a pričom prejavila svoju náročnost aj otvorenosț voči problému, nech bol velký či malý, nech patril vede alebo človečine.

Eva Fordinálová konštatuje, že Hollého umelecká činnosṫ a dielo „prešli vo vývine našej literárnej vedy rôznymi interpretačnými peripetiami, do ktorých sama premyslene a vždy so znalostou podstaty genologického, estetického či poetologického problému nevstupuje tenzijne. Naopak, prostredníctvom súvislostí a s dôkladnou znalostou historiografie, filozofie, estetiky aj docenením prítomnej spoločensky prejavovanej alegorickosti voči básnikovi Jánovi Hollému, ktorú on svojou poéziou dodnes iniciuje, Eva Fordinálová sleduje z genologického, verzlogického a literárnoestetického prístupu, aký si básnik vypracoval, svoje výkladové a komparatívne trajektórie $\mathrm{k}$ básnikovi, a to aj preto, lebo vie, že „klasicistické dielo Jána Hollého je zároveň klasickým príkladom na obsiahnutie celej tejto jednoty a boja protikladov [...]“, paradoxne aj s dávkou rezignácie konštatuje, „že sme ešte stále nepochopili všetko“, čo súvisí s jeho životom, úsilím, tvorbou a odkazom po súčasnost'.

Literárna historička Eva Fordinálová sa vydala cestou ponorného odkrývania Hollého literárnej morfológie, literárnej estetiky, poetológie iniciovanej aj žánrovo tvorbou antických velikánov, teda ako z rovín dnešného poznania klasicistického konceptu, ním zhodnocovanej krásy, ucelenosti a uzavretosti výrazu i výpovede porozumiet dnešnými postojmi poézii a ním prežitej skutočnosti Hollého, ako napísala, osobitému, sebestačnému svetu utváranému z umenia slova, talentom tvorivosti, poznaním minulosti a dotváranej do hodnoty prekračujúcej čas v jeho prirodzenom pohybe, čo sa najskôr uskutoční za pomoci osobnej mravnej ustálenosti. Básnik Ján Hollý našiel svoju vykladačku, profesorka Eva Fordinálová si ním a jeho tvorbou overovala a upevňovala svoje ludské aj profesijné istoty, stalo sa tak na úžitok nás všetkých.

E-mail: viera.zemberova@ff.unipo.sk 